\title{
Picogram per Second
}

National Cancer Institute

\section{Source}

National Cancer Institute. Picogram per Second. NCI Thesaurus. Code C85783.

Picograms per second. 